\title{
Obituary.
}

\section{ADOLF GUSSEROW (1836-1906).}

BY the death of Gusserow, one of the most prominent pioneers of modern gynæcology in Germany has passed away, and this will assuredly call forth sincere sympathy in Great Britain.

The deceased professor always followed the progress of medical science in Great Britain with special interest, and many of the leading British obstetricians and gynæcologists, e.g., A. R. Simpson, Lawson Tait, Playfair, Priestley, and Smyly, he numbered amongst his personal friends.

Gusserow's relations with Great Britain arose from his travels during his early medical training. Before he started on his journey the brilliant work of such men as Sir Spencer Wells and Sir James Y. Simpson had spread the renown of British gynæcology over the whole world. Gusserow also felt an irresistible desire to see for himself the practice of these great men. He therefore spent a considerable time in the British Isles investigating the burning questions of that time.

He owed much practical knowledge and stimulation to his sojourn on that side of the Channel, and he described his experiences in a detailed record of his travels (Geburtshülfe und Gynälologie in Grossbrittanien; ein Reisebericht. Monatsschrift für Geburtskunde, 1864) with a due appreciation of the conditions peculiar to Great Britain.

Gusserow was one of the warmest admirers of the genial Sir James Y. Simpson, and the obituary notice of this great physician which he publicly delivered as Rector of the University of Zürich (Zur Errinerung an Sir J. Y. Simpson, Berlin, 1871), holds a foremost place amongst the necrologies of the discoverer of chloroform which appeared on the Continent.

In 1894 Gusserow was elected an Hon. Fellow of the Obstetrical Socicty of London, an honour which he highly prized.

Adolf Ludwig Sigismund Gusserow (to give him his full name) was born on the 8th July, 1836, and was the son of a well-known physician in Berlin; he studied medicine in Berlin, Würzburg and Prague. After passing his state examination he discharged the duties of assistant in the University Frauenklinik, under Edward Martin, and from there qualified as Privatdocent (1865).

After an exceptionally rapid career (having regard to Continental 
conditions), during which he was appointed to the Professorial chair at Utrecht (1867), Zürich (1867--72) and Strassburg (1872-78) successively, and while still a comparatively young man, he was called back to Berlin, the leading University in Germany.

This brilliant career he owed to his eminent intellectual and moral qualities, thanks to which he acquired a first-class reputation as an academic teacher. Endowed with a clear, critical judgment, he sought by intimate personal intercourse to influence his pupils in a simple and homely way, making it his chief object to train them to become capable and conscientious practitioners. In this he succeeded so completely that the men trained by Gusserow enjoy the highest repute throughout the German empire.

It fell to his lot in Zürich, in Strassburg, and in Berlin to found new institutions in accordance with modern ideas. Thanks to his talent for organization, he succeeded in these tasks, and the State institutions founded by Gusserow soon grew into the full flower of success and quickly won the confidence of the public.

That Gusserow was a humane, scientific, conscientious physician was not the least factor in this result. He had, also, in consequence a large private practice in Zürich and a still larger one in Berlin. Poor and rich were equally attracted to the friondly, warm-hearted and ever-ready helper, and in the fashionable and wealthy circles of the German capital he was much sought after as an accoucheur and as a much-trusted adviser.

It was not as a voluminous author, but as a practitioner that he was conspicuous; nevertheless, his literary work was always sound and thorough. His best known work is the section on the new growths of the uterus in the "Handbuch der deutschen Chirurgie," edited by Pitha and Billroth.

Two years ago progressive illhealth caused Gusserow to resign those of his official duties to which he no longer felt equal. His intellectual power, however, remained undiminished till shortly before his death, on February 6th, and to the last he set an example of indefatigable faithfulness to duty, by the manner in which he continued, with his accustomed zeal, to devote himself to the editorship of the Archiv für Gynäkologie, a journal, the high standard and pre-eminent position of which, he and Leopold so successfully co-operated to maintain.

Wilhelm Nagei (Berlin). 